up the challenge? Perhaps some of us feel threatened by a change in emphasis, or maybe we don't understand the techniques of educational/behavioural approaches and feel uncomfortable with them. Most of us tend to seek the solutions we are most comfortable and familiar with-thus surgeons recommend surgery, engineers propose design changes, educators advocate teaching, and epidemiologists suggest that more data be collected!

The techniques of education and behaviour modification are certainly different from those of environmental change, and also are practised by different professional groups, many of whom don't speak the language of the other players. It is possible that those who espouse the passive approach might learn a great deal from those who've had to adapt to active approaches to achieve their objectives, and vice versa.

I'd like to suggest that we're in danger of becoming lazy (passive even?) in choosing those interventions that are 'easy' to do and neglecting those we consider too difficult. Of the 'three Es', education remains a key element. Without it enforcement and engineer- ing approaches cannot be effective. Before any countermeasures are implemented, politicians, injury control professionals, and the commu $\overline{2}$. nity, all need to be educated, influenced, ando bullied into supporting change. The key too using active strategies constructively is educa tion-we need to improve the education rathen than dismiss it.

1 Waller JA. Reflections on a half century of injury control Am F Public Health 1994; 84: 664-70.

2 Baker SP. Prevention of childhood injuries. Med f Ausţ

Ton MH, Baker SP, Teret SP, et al. Saving children. New York: Oxford University Press, 1991.

4 Minchom PE, Sibert JR, Newcombe RG, Bowley MA. Doeshealth education prevent childhood accidents? Postgraf Med F 1984; 60: 260-2.

5 Robertson LS. Injury epidemiology. New York: Oxford University Press, 1992.

6 Avery JG, Jackson RH. Children and their accidents. London. Edward Arnold, 1993.

7 National Committee for Injury Prevention and ControliN Meeting the challenge. New York: Oxford University Press, 1989.

8 Towner EML. The role of health education in childhood injury prevention. Injury Prevention 1995; 1: 53-8.

9 Hill D, White V, Marks R, Borland R. Changes in sun related attitudes and behaviours, and reduced sunburm prevalence in a population at high risk of melanoma. Eur Cancer Prev 1993; 2: 447-56.

10 Willinger $M$, Hoffman $H J$, Hartford RB. Infant sleep position and risk for sudden infant death syndrome Pediatrics 1994; 93: 814-9.

\title{
From educator to strategic activist for injury control
}

\author{
Elizabeth McLoughlin
}

The important question is not: are you for or against education to prevent injuries? The essential question is: what most effectively prevents a certain type of injury? My first 10 years working to prevent burns led me to believe that product and environmental modification to reduce the risk of injury was more effective than education about safe behaviors. As a teacher, this was a shift for me. I had started working as director of burn prevention at a pediatric burn unit in 1973, after earning a masters degree in education and teaching for seven years in classrooms from Head Start to adult evening college.

Several articles about our early prevention work highlight some of the lessons I learned. One article published in 1977 detailed a decrease in the number of children burned by sleepwear ignition who were admitted to our unit, coincident with the establishment of the children's flame resistant sleepwear standard. ${ }^{1}$ A pair of papers, published in 1982, concluded that a five year, $\$ 1$ million public education burn prevention program resulted in some knowledge gains among children participating in classroom activities, but had no measurable effect in reducing burn rates in metropolitan
Boston. ${ }^{23}$ Another, published in 1985, concluded that county legislation requiring resi dential smoke detectors resulted in mores homes being protected by working detectors, compared with a county without that require-윽 ment. Homes built after 1975, when buildings codes required 'hard-wired' detectors in al new construction, were more likely to haven working detectors regardless of county. Personal letters using threat or persuasion that were sent by fire chiefs to home owners failed to ${ }^{\omega}$ have a measurable effect on detector use. ${ }^{4}$ श्र

Environmental change is measurably effec운 tive in preventing injury. In addition to flame resistant sleepwear, examples include changing vacuum cleaner electrical cords to prevents mouth burns in toddlers, ${ }^{5}$ window guards too prevent childhood falls, ${ }^{6}$ the packaging of drugs, ${ }^{7}$ the design of safer cars, ${ }^{8}$ and of safer highways. ${ }^{9}$

The primary reason why we in public healtho should, whenever possible, focus on making environments rather than behaviors safer is thate environmental changes protect whole populations. Safe behaviors must be adopted individual by individual. They must be practised routinely, maintained over a lifetime, and be 
powerful enough to overcome the multiple and complex factors contributing to injury causation. Unfortunately and sadly, experience proves that safe behavior by itself is often not enough.

Education to persuade whole populations of individuals to adopt safe behaviors is a less effective tool for injury control. Education aims to increase knowledge, but one's knowledge does not always determine one's behavior. Even if they were successful in persuading people to behave safely, educational interventions must be constantly repeated, because people forget and populations change. Additionally, educational interventions are least likely to reach and influence highest risk populations, given the developmental characteristics of the very young, the very old and adolescents, and the consequences of poverty and social isolation. Further, such interventions tend to put the burden of change on those with the least resources.

However, education is not the only tool for behavior change. For example, some riders wear motorcycle helmets because they agree with educational messages about their usefulness; other riders do so only because it is an enforced law with large fines attached to noncompliance. Regardless of why the helmet is used, helmets protect riders from brain injury. ${ }^{10}$

Injurious incidents are complex and multifaceted, and so are interventions to prevent them. Recent developments with children and airbags illustrate how several strategies must be employed to prevent specific kinds of injuries. Airbags were developed and installed to protect car occupants in crashes. Airbag performance standards were based on adult body size and relatively high speed crashes. While airbags have saved 1500 lives in the United States through November 1996, they have also deployed in low impact crashes and killed 19 drivers and 31 children as front seat occupants. ${ }^{11}$ These include infants in rearfacing car seats, unrestrained children, and adults of small stature. Consequently, federal officials are modifying airbag performance standards, car manufacturers are attaching highly visible warning labels in cars, and police are enforcing restraint laws. At the same time, public/private partnerships are intensifying education campaigns about the use of proper restraints (seat belts and car seats) and placement of infants and small children (always in the back seat). The redesigned airbag will continue to provide protection in crashes, provided that vehicle occupants practice the necessary safe behaviors. However, additional product modifications are needed. For example, building standard anchorages and/or child safety seats into the back seats of cars will increase the likelihood that children are properly restrained. It is beneficial when engineering, regulation, enforcement, and education converge to support a safer environment.

More and more, the merits of injury control interventions are argued in economic terms. What is a life worth, and how expensive is the proposed measure to save that life? If education is perceived to be cheaper, some people advocate using it to change people rather than using engineering and political capital to change products and environments. Efforts to regulate products and environments tend to draw political and corporate opposition, because they force changes which traditional market forces have not yet demanded. In contrast, education campaigns draw corporate and political support because they appear to cost less, focus on individual liberty and responsibility, and foster good public relations for police or fire departments, corporations, healthcare facilities, or insurance companies. But is this more effective in preventing injuries? The weight of the evidence from the literature suggest not.

An interesting analysis from New Zealand examines the costs and potential effectiveness of school instruction versus traffic calming to prevent childhood pedestrian injuries. ${ }^{12}$ Traffic calming strategies include modifications of street surfaces, widths, shoulders, and parking practices. The authors determined that these are potentially more cost effective in protecting children than are school based instruction.

Some types of injury do not lend themselves easily to product and environmental protection. Interpersonal violence is one such problem. However, even here, there are public policy interventions which will reduce risk. Reducing the saturation of neighborhoods by alcohol outlets and advertising, ${ }^{13}$ and increasing the cost of alcohol, ${ }^{14}$ may reduce alcohol related violence. In the United States, a rational gun control policy which reduces handgun availability would reduce the lethality of interpersonal violence. ${ }^{15}$ Taking on powerful industry forces such as the alcohol lobby and the National Rifle Association make these injury control interventions among the most difficult challenges in public health today-but despite the challenges, important advances are being made.

However, reducing the availability of alcohol and guns do not address the root causes of violence, for which there are no single or simple solutions. Interventions require multifaceted public policy and community based approaches, including economic development, improvement in education, jobs, child care, and housing, as well as programs aimed at changing the behavior of violent people. Education to increase public support for these approaches is essential to their implementation.

If strategies to prevent injuries must transcend individual adoption of safe behaviors, what, then, is the role of educators? They are key participants in strategic action for injury control. Their training well equips them to distill and translate academic research findings into user friendly, lay terms, thus providing essential knowledge to policy makers, engineers and city planners, community activists, the media, and voters. They are trained to think and speak clearly 'on their feet' and thus can voice sound public policy recommendations through the popular media of TV, radio, and newspapers. They can debate with corpo- 
rate leaders and policy makers about the merits of a proposed policy. They can reach out to those whose lives have been tragically altered by injury, and help them channel their grief into strategic action. They can mentor young professionals who will work to prevent injuries well into the 21 st century.

Injury control educators should not focus on the daunting task of trying to convince every individual to behave safely. In fact, they have a far broader charge. They must facilitate the implementation of policies that most effectively create a safer population.

1 McLoughlin E, Clarke N, Stahl K, Crawford JD. One pediatric burn unit's experience with sleep-wear related injuries. Pediatrics 1977; 4:405-9.

2 McLoughlin E, Vince C, Lee A, Crawford JD. Project Burn Prevention: outcome and implications. Am $\mathscr{f}$ Public Health 1982; 72: $241-7$.

3 MacKay AM, Rothman KJ. The incidence and severity of burn injuries following Project Burn Prevention. $A m$ I Public Health 1982; 72: 248-52.

4 McLoughlin E, Marchone M, Hanger L, German P, Baker SP. Smoke detector legislation: its effect on owneroccupied homes. Am f Public Health 1985; 75: 858-62.
5 Sorenson B. Prevention of burns and scalds in a developed country. F Trauma 1976; 16: 249-58

6 Spiegel CN, Lindaman FC. Children can't fly: a program to prevent childhood morbidity and mortality from window falls. Am ₹ Public Health 1977; 76: 1143-7.

7 Rodgers GB. The safety effects of child resistant packaging for oral prescription drugs: two decades of experienced fAMA 1996; 275: $1661-5$.

8 Robertson LS. Automobile safety regulations and death. reductions in the United States. Am $\mathcal{F}$ Public Health 1981 71: $818-22$.

9 Kraus JF, Anderson CL, Arzemanian S, Salatka MO Hemyari P, Sun G. Epidemiological aspects of fatal and severe injury urban freeway crashes. Accid Anal Prev 199325: $229-39$

10 Kraus JF, Peek C, MacArthur DL, Williams A. The effect of the 1992 California motorcycle helmet law on motorcycle crash fatalaties and injuries. $7 A M A$ 1994; 272: $1506-11$

11 National Highway Traffic Safety Administration, US DOT Air bag deactivation (notice of rule making: 49 CFR ParO

595) http://www.nhtsa.dot.gov
12 Roberts I, Ashton T, Dunn R, Lee-Joe T. Preventing chil $\overrightarrow{4}$ pedestrian injury: pedestrian education or traffic calming pedestrian injury: pedestrian education or traffic calminges

Aust f Public Health 1994; 18: 209-12.

Scribner RA, MacKinnon DP, Dwyer JH. The risk â assaultive violence and alcohol availability in Los Angeles County. Am f Public Health 1995; 85: 335-40.

14 Cook PJ, Moore MJ. Violence reductions through restricitions on alcohol availability. Alcohol Health and Research World 1993; 17: 151-6.

15 Adler KP, Barondess JA, Cohen J. Firearm violence an $\$$ public health: limiting the availability of guns. $\mathscr{F} A M A$ 1994; 271: $1281-3$.

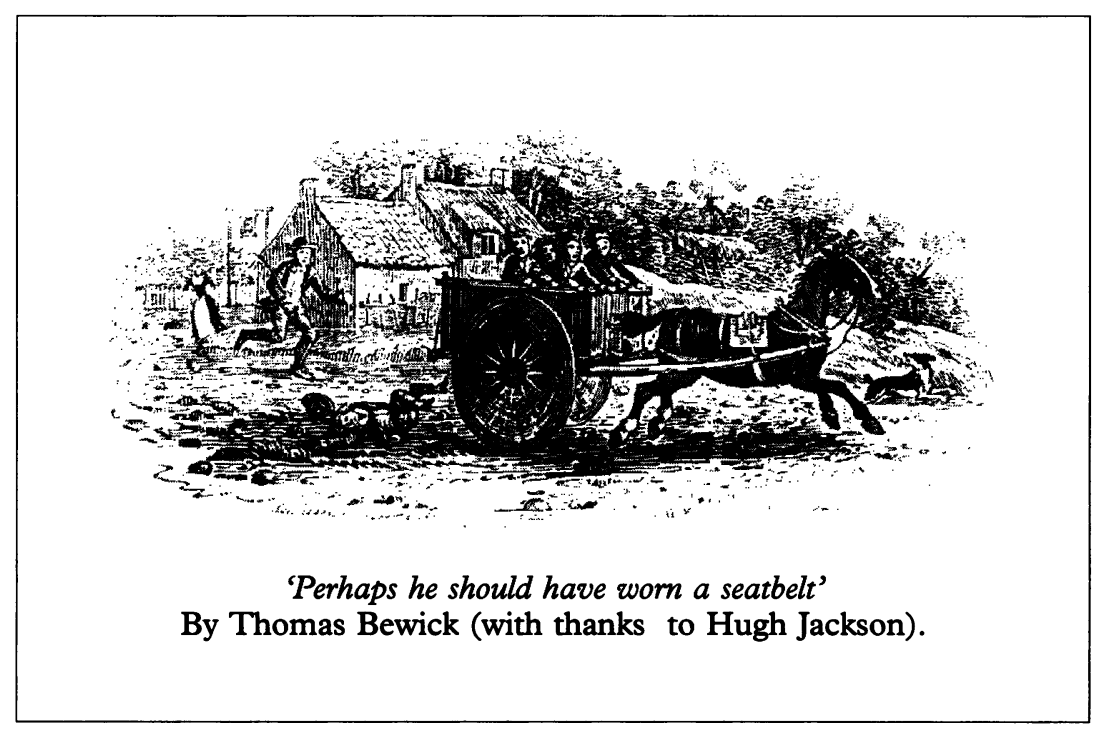

